\title{
PRZEPROWADZENIE POSTĘPOWANIA DOWODOWEGO PODCZAS USPRAWIEDLIWIONEJ NIEOBECNOŚCI OSKARŻONEGO LUB JEGO OBROŃCY NA ROZPRAWIE
}

\begin{abstract}
Abstrakt: Przedmiotem opracowania jest analiza treści art. 378a k.p.k., dodanego do kodeksu postępowania karnego 5 października 2019 roku na mocy ustawy z dnia 19 lipca 2019 roku o zmianie ustawy - Kodeks postępowania karnego oraz niektórych innych ustawy. Wskazany przepis prawny umożliwia przeprowadzanie postępowania dowodowego podczas nieobecności oskarżonego lub jego obrońcy nawet wówczas, gdy usprawiedliwili oni należycie swoje niestawiennictwo. Autorka podejmuje rozważania nad zasadnością wprowadzenia do ustawy karnoprocesowej art. 378a k.p.k., zastanawia się także nad prawidłowością jego konstrukcji i spójnością z innymi przepisami kodeksu postępowania karnego. W konsekwencji swoich przemyśleń znajduje wiele wad wskazanej regulacji prawnej oraz, odwołując się do wykładni systemowej i funkcjonalnej, podejmuje próbę złagodzenia negatywnych skutków wprowadzenia do polskiego systemu prawnego możliwości przeprowadzenia postępowania dowodowego podczas należycie usprawiedliwionej nieobecności oskarżonego lub jego obrońcy na rozprawie.
\end{abstract}

Słowa kluczowe: nieobecność oskarżonego na rozprawie, postępowanie dowodowe pod nieobecność oskarżonego, postępowanie dowodowe, prawo do obrony, oskarżony

\section{UWAGI WPROWADZAJĄCE}

W dniu 5 października 2019 roku weszła w życie ustawa z dnia 19 lipca 2019 roku o zmianie ustawy - Kodeks postępowania karnego oraz niektórych innych ustaw $^{1}$. W świetle postanowień tej ustawy do kodeksu postępowania karnego dodano art. 378a k.p.k., który — ogólnie rzecz ujmując — przewiduje możliwość przeprowadzenia postępowania dowodowego bez udziału oskarżonego lub jego obrońcy na rozprawie. Ta nowa instytucja karnoprocesowa - w zamyśle ustawodawcy — ma przeciwdziałać przewlekłości postępowania karnego w ten sposób, że nieobecność

1 Dz.U. z 2019 r. poz. 1694. 
oskarżonego lub jego obrońcy na rozprawie, nawet jeżeli będzie usprawiedliwiona, nie musi blokować czynności przeprowadzania dowodów przez sąd, w tym nie musi być przeciwwskazaniem do przesłuchania świadków, którzy stawili się na dany termin rozprawy. W uzasadnieniu projektu ustawy odczytujemy, że

W praktyce orzeczniczej sądów bardzo istotnym czynnikiem wpływającym na przedłużanie się trwania postępowań jest konieczność odraczania i przerywania rozpraw w sytuacji usprawiedliwionej nieobecności oskarżonych i obrońców. Aktualnie zaistnienie tego typu sytuacji bezwzględnie powoduje zaniechanie prowadzenia czynności na rozprawie w danym terminie. Powoduje to, oprócz przewlekłości postępowania, duże koszty społeczne i finansowe, w szczególności polegające na konieczności ponownego stawienia się w innym terminie, nieraz kilkukrotnego, świadków i biegłych, którzy nie mogli być przesłuchani z uwagi na usprawiedliwioną nieobecność stron i pełnomocników ${ }^{2}$.

Z przytoczonego fragmentu uzasadnienia wynika, że głównym celem wprowadzenia do ustawy karnoprocesowej przepisu art. 378a k.p.k. jest dążenie do przeciwdziałania obstrukcji procesowej oraz przyspieszenie postępowania karnego. W dalszej części artykułu zaprezentowano syntetyczne rozważania nad zasadnością wprowadzenia do systemu prawa karnego procesowego rzeczonego przepisu prawnego, prawidłowością jego konstrukcji oraz spójnością z innymi przepisami kodeksu postępowania karnego.

\section{OBOWIĄZEK POUCZENIA O TREŚCI ART. 378A K.P.K.}

Szczegółową analizę treści art. 378a k.p.k. poprzedźmy krótką refleksją dotyczącą kwestii poinformowania oskarżonego o możliwości przeprowadzenia postępowania dowodowego podczas nieobecności oskarżonego lub jego obrońcy, choćby owa nieobecność była usprawiedliwiona. Zgodnie z art. 353 § 4 k.p.k., który normuje problematykę zawiadomienia o terminie rozprawy głównej oraz wezwania na rozprawę, „Doręczając oskarżonemu wezwanie na rozprawę albo zawiadomienie o jej terminie, poucza się go o treści przepisów art. $100 \S 3$ i 4, art. 374, art. 376, art. 377, art. 378a, art. 419 § 1, art. 422 i art. 447 §”. Oskarżony zobowiązany bądź wyłącznie uprawniony do stawienia się na rozprawę główną jest zatem informowany o: (1) kwestii doręczenia wyroku, a także postanowień albo zarządzeń wydanych poza rozprawą (art. 100 § 3 i 4 k.p.k.); (2) kwestii obecności na rozprawie (art. 374 k.p.k.); (3) konsekwencji opuszczenia przez oskarżonego sali lub niestawiennictwa na rozprawie, a także niezdolności oskarżonego do udziału w rozprawie (art. 376 k.p.k., art. 377 k.p.k.); (4) możliwości prowadzenia postępowania dowodowego bez udziału oskarżonego lub jego obrońcy (art. 378a k.p.k.); (5) konsekwencji niestawiennictwa stron przy ogłaszaniu wyroku (art. 419 $\S 1$ k.p.k.); (6) kwestii związanej ze złożeniem wniosku o sporządzenie i doręcze-

${ }^{2}$ Z uzasadnienia projektu ustawy nowelizacyjnej, s. 42-43. 
nie uzasadnienia (art. 422 k.p.k.) oraz (7) niemożności powoływania pewnych zarzutów w apelacji (art. $447 \S 5$ k.p.k.). Ponadto, jeżeli oskarżony ma prawo, nie zaś obowiązek uczestniczenia $\mathrm{w}$ rozprawie, to jest on dodatkowo pouczany o treści art. $402 \S 1$ zdanie trzecie k.p.k., czyli o tym, że oskarżony nie musi zostać zawiadomiony o nowym terminie rozprawy, nawet jeśli nie uczestniczył w rozprawie przerwanej (art. 353 § 4a k.p.k.). W istocie art. 353 § 4 i 4a k.p.k. stanowią o obowiązku pouczenia przez organ procesowy. Ponieważ obowiązek ten wyrażony jest explicite w ustawie karnoprocesowej, to winien być on analizowany w sprzężeniu z art. $16 \S 1$ k.p.k., zgodnie z którym jeżeli organ prowadzący postępowanie jest obowiązany pouczyć uczestników postępowania o ciążących obowiązkach i o przysługujących im uprawnieniach, brak takiego pouczenia lub mylne pouczenie nie może wywoływać ujemnych skutków procesowych dla uczestnika postępowania lub innej osoby, której to dotyczy. Wskazana, a wynikająca z art. $16 \S 1$ k.p.k. norma prawna jest istotna z punktu widzenia toku dalszego wywodu, do normy tej zatem jeszcze powrócimy.

Zwróćmy także uwagę, że zasadniczo oskarżony ma prawo wziąć udział w rozprawie, chyba że przewodniczący lub sąd uzna jego obecność za obowiązkową (art. $374 \S 1$ k.p.k.) ${ }^{3}$. Natomiast zgodnie z art. 374 § 2 k.p.k. w sprawach o zbrodnie jego obecność jest obowiązkowa wyłącznie podczas otwarcia przewodu sądowego (zwięzłego przedstawienia zarzutów oskarżenia) (art. 385 k.p.k.) oraz przy pierwszym przesłuchaniu (art. 386 k.p.k.). Wymaga podkreślenia, że to właśnie po pierwszym przesłuchaniu oskarżonego aktualizuje się obowiązek przewodniczącego składu orzekającego pouczenia oskarżonego o prawie zadawania pytań osobom przesłuchiwanym oraz składania wyjaśnień co do każdego dowodu. Ów obowiązek sądu pouczenia oskarżonego, wynikający z art. $386 \S 2$ k.p.k., również winien być interpretowany w sprzężeniu $\mathrm{z}$ art. $16 \S 1$ k.p.k. Wyrażone w art. $386 \S 2$ k.p.k. prawo oskarżonego do bycia pouczonym jest istotnym składnikiem jego prawa do obrony, wyrażającym możliwość zadawania przez oskarżonego pytań każdej osobie przesłuchiwanej, a także złożenia wyjaśnień co do każdego dowodu. Ważnym składnikiem prawa do obrony jest także uprawnienie do odbierania wrażeń zmysłowych przez oskarżonego w trakcie przeprowadzania czynności dowodowych. Uprawnień tych oskarżony zasadniczo nie może zostać pozbawiony, pozbawienie zaś oskarżonego takiego prawa stanowiłoby rażące naruszenie art. 6 k.p.k. Urzeczywistnienie wskazanych uprawnień oskarżonego naturalnie może nastąpić wyłącznie wówczas, gdy oskarżony posiadł wiedzę co do tego, że takie uprawnienia mu przysługują, dlatego też obowiązek informacyjny, o którym pisano wcześniej, jest tak istotny dla oskarżonego (należy zwrócić uwagę, że, po pierwsze, nie każdy oskarżony musi

3 Więcej na temat obecności oskarżonego na rozprawie zob. D. Drajewicz, Nieobecność oskarżonego na rozprawie głównej (art. 376 k.p.k.), „Prokuratura i Prawo” 2014, nr 5, s. 25-50; idem, Nieobecność oskarżonego na rozprawie głównej (art. 377 k.p.k.), „Prokuratura i Prawo” 2014, nr 7-8, s. 39-56; idem, Nieobecność oskarżonego na rozprawie w znowelizowanym Kodeksie postępowania karnego, „Monitor Prawniczy” 2015, nr 11, Legalis. 
mieć wiedzę co do takich uprawnień, po drugie, nie każdy oskarżony musi korzystać także z pomocy obrońcy).

\section{ANALIZA ART. 378A K.P.K. W KONTEKŚCIE OBOWIĄZKU INFORMACYJNEGO WYNIKAJĄCEGO Z ART. 386 § 2 K.P.K.}

\section{Przejdźmy teraz do bliższej analizy art. 378a k.p.k. Zgodnie z dyspozycją § 1:}

Jeżeli oskarżony lub obrońca nie stawił się na rozprawę, będąc zawiadomiony o jej terminie, sąd, w szczególnie uzasadnionych wypadkach, może prowadzić postępowanie dowodowe podczas jego nieobecności, chociażby usprawiedliwił należycie niestawiennictwo, a w szczególności przesłuchać świadków, którzy stawili się na rozprawę, nawet jeżeli oskarżony nie złożył jeszcze wyjaśnień.

\section{Natomiast wedle $\S 2$ :}

W wypadku, o którym mowa w § 1, oskarżonego lub obrońcę należy wezwać lub zawiadomić o nowym terminie rozprawy, jeżeli termin ten nie był im znany. Przy doręczeniu wezwania lub zawiadomienia należy również doręczyć pouczenie, o którym mowa w $§ 7$.

Co za tym idzie - jeżeli oskarżony został zawiadomiony o terminie rozprawy, istnieje możliwość przeprowadzenia postępowania dowodowego nawet wówczas, gdy oskarżony należycie usprawiedliwił swoje niestawiennictwo (na przykład przesyłając do sądu informację o swojej chorobie i pobycie w szpitalu). Tym samym art. 378a k.p.k. należy traktować jako lex specialis względem art. 117 $\S 2$ k.p.k., zgodnie z którym czynności nie przeprowadza się, jeżeli osoba uprawniona usprawiedliwiła należycie niestawiennictwo i wnosi o nieprzeprowadzanie czynności bez jej obecności. Co więcej, możliwość przeprowadzenia postępowania dowodowego na zasadach, o których stanowi art. 378a k.p.k., istnieje również wówczas, gdy oskarżony nie złożył jeszcze wyjaśnień. W takiej konfiguracji procesowej, skoro oskarżony nie złożył jeszcze wyjaśnień, albowiem nie stawił się na pierwszy termin rozprawy z powodu obiektywnej niemożliwości stawiennictwa, które należycie usprawiedliwił, to naturalnie nie mógł zostać jeszcze pouczony o prawie do zadawania pytań osobom przesłuchiwanym oraz składania wyjaśnień co do każdego dowodu (jak już to eksponowano, obowiązek niniejszego pouczenia aktualizuje się po pierwszym przesłuchaniu). Skoro zaś nie został jeszcze pouczony o wskazanych uprawnieniach, to brak takiego pouczenia — zważmy, brak pouczenia przed dokonaniem czynności karnoprocesowej relewantnej z punktu widzenia tego pouczenia — nie może wywoływać — w świetle dyspozycji art. 16 $\S 1$ k.p.k. - negatywnych konsekwencji dla tego uczestnika postępowania karnego, który nie został pouczony. Niewątpliwie taką negatywną konsekwencją dla oskarżonego może być niemożność zadania pytania osobie przesłuchiwanej, która wynikała z braku pouczenia o takim uprawnieniu, które z kolei wynikało z obiek- 
tywnej niemożności stawiennictwa na czynność przesłuchania (na pierwszy termin rozprawy). Problem ten wskazywano już na etapie projektowania przepisów ustawy nowelizacyjnej:

Przeprowadzenie postępowania dowodowego pod jego nieobecność z samej swej istoty narusza bowiem przysługującą mu gwarancję procesową w postaci prawa do sprawiedliwego i publicznego przesłuchania przez właściwy, niezależny i bezstronny sąd. Jak wskazuje się — kategoria ta obejmować będzie prawo oskarżonego do swobodnego składania wyjaśnień — zarówno po odczytaniu mu aktu oskarżenia, jak i w przypadku każdego przeprowadzonego na rozprawie dowodu. Trudno w niniejszej sytuacji przyjąć, że oskarżony nie stawiając się na rozprawie (którego nieobecność jest uzasadniona), dobrowolnie rezygnuje z tego uprawnienia. Oznacza to, że właściwie każdorazowo dochodzi do naruszenia gwarancji procesowych oskarżonego, co czyni przepis art. 378a k.p.k. nieefektywnym w proponowanej formie — nie tylko nie przyspieszy on w sposób faktyczny postępowania, ale może prowadzić do powielania przeprowadzonego pod nieobecność oskarżonego postępowania dowodowego, co stoi w sprzeczności z zasadą ekonomiki procesowej ${ }^{4}$.

Co prawda, brak pouczenia, o którym mowa w art. $16 \S 1$ k.p.k., do tej pory interpretowany był głównie (choć nie wyłącznie) w kontekście nieprawidłowego postępowania organów procesowych, a nie takich konstrukcji legislacyjnych, które uniemożliwiają urzeczywistnienie obowiązku pouczenia, to jednak wątpliwości budzić nie powinno, że brak pouczenia może być również analizowany w drugim ze wskazanych kontekstów. Na tle określonej już konfiguracji związanej z interpretacją art. 378a § 1 k.p.k., art. $386 \S 2$ k.p.k. i art. $16 \S 1$ k.p.k. dochodzimy do następującego wniosku: oskarżony (lub jego obrońca), nie stawiwszy się na pierwszy termin rozprawy po należytym usprawiedliwieniu, nie zostaje z powodu swojego usprawiedliwionego niestawiennictwa przesłuchany, a tym samym nie zostaje pouczony o prawie do zadawania pytań osobom przesłuchiwanym i wypowiedzenia się co do każdego dowodu, co sprawia, że nie może ponieść negatywnych konsekwencji tego stanu rzeczy, lecz to wszystko nie stoi na przeszkodzie przeprowadzaniu postępowania dowodowego, w tym przesłuchania świadków podczas jego nieobecności. W sposób oczywisty wskazane zdanie jest wewnętrznie sprzeczne. Już z samej swej istoty negatywną dla oskarżonego konsekwencją może być na przykład przesłuchanie przez sąd na pierwszym terminie rozprawy świadka, któremu oskarżony nie mógł zadać pytań z uwagi na brak pouczenia o takim uprawnieniu $\mathrm{z}$ uwagi na jego usprawiedliwioną nieobecność podczas pierwszego terminu rozprawy. W świetle tego należy uznać, że dyspozycja art. 378a $\S 1$ k.p.k. jest niedostosowana do treści art. $386 \S 2$ k.p.k. interpretowanego w związku z art. $16 \S 1$ k.p.k. Urzeczywistnienie takiej konfiguracji procesowej, a mianowicie przesłuchanie świadka, któremu oskarżony nie mógł zadać pytań z uwagi na brak poinformowania go o takim uprawnieniu z powodu jego należycie

${ }^{4}$ Z opinii Rady Legislacyjnej przy Prezesie Rady Ministrów o projekcie ustawy o zmianie ustawy - Kodeks postępowania karnego oraz niektórych innych ustaw z dnia 25 stycznia 2019 roku, RL-033-6/18. 
usprawiedliwionej nieobecności, rażąco narusza zagwarantowane w art. 6 k.p.k. prawo do obrony. Argumentacja odwołująca się do tego, że możliwość skorzystania przez sąd $\mathrm{z}$ uprawnienia wskazanego $\mathrm{w}$ art. 378a $\S 1$ k.p.k. jest fakultatywna, a nadto następuje w szczególnie uzasadnionych wypadkach nie jest przekonująca, de lege lata nie można bowiem wykluczyć takich sytuacji, w których dojdzie do przeprowadzenia postępowania dowodowego podczas usprawiedliwionej nieobecności oskarżonego na rozprawie, w sytuacji, w której nawet wniósł on o nieprzeprowadzenie czynności podczas jego nieobecności.

Należy także stanowczo przeciwstawić się zaprezentowanej w uzasadnieniu projektu ustawy argumentacji, zgodnie z którą

Przepis art. 378a k.p.k. jest przewidziany w formule zbliżonej do tzw. sądowego zabezpieczenia dowodu, które jest znane procedurze chociażby w art. $316 \S 3$ k.p.k. Nie jest to zatem prowadzenie rozprawy w nieobecności strony lub jej przedstawiciela, a przeprowadzenie dowodu, i to tylko fakultatywnie - w szczególnie uzasadnionych wypadkach, jeżeli sąd uzna taką potrzebę.

Jeżeli zdaniem projektodawcy instytucja przewidziana w art. 378a k.p.k. nie jest „prowadzeniem rozprawy w nieobecności strony lub jej przedstawiciela”, ale „przeprowadzeniem dowodu”, to pojawia się pytanie, na jakim forum rozstrzygania (jeżeli nie na rozprawie, albowiem nie ma być to „przeprowadzanie rozprawy w nieobecności strony") ów dowód ma być przeprowadzany oraz jakie zasady postępowania na tym forum należałoby przyjać? To znaczy, czy z takiego założenia wynika, że przeprowadzenie dowodu miałoby nastąpić poza rozprawą główną? A dodatkowo, gdzie w treści art. 378a k.p.k. znajdziemy potwierdzenie takiego założenia, które wyraził projektodawca? Należy uznać, że taki wniosek pozostawałby sprzeczny z wykładnią językową art. 378a k.p.k. — już w początkowych fragmentach $\S 1$ wskazano bowiem: „Jeżeli oskarżony lub obrońca nie stawił się na rozprawę [...] można przeprowadzić postępowanie dowodowe podczas jego nieobecności”, w $\S 2$ zaś tego przepisu mowa o kolejnym terminie rozprawy („najpóźniej na kolejnym terminie rozprawy"). Należy zatem uznać, że - wbrew temu, co zostało wskazane w uzasadnieniu projektu ustawy — czynność przeprowadzenia dowodu, o której mowa w art. 378a k.p.k., ma miejsce na rozprawie, która odbywa się podczas nieobecności oskarżonego lub jego obrońcy ${ }^{5}$. Przyjmując, że przeprowadzenie

5 Inaczej J. Zagrodnik: „Z perspektywy konstrukcyjno-teoretycznej zasadnicze znaczenie ma dalsza część uzasadnienia rozwiązania normatywnego przewidzianego w art. 378a KPK, w której projektodawca na kanwie stwierdzenia, że w razie usprawiedliwionego niestawiennictwa na rozprawie uprawnionych osób, nie można jej dalej kontynuować i powinna ulec ona odroczeniu lub przerwaniu, przyjmuje, że nie powinno to wykluczać samego tylko przeprowadzenia dowodów, zwłaszcza przesłuchania osób, które stawiły się na rozprawie. W ten sposób projektodawca zakłada w istocie w odniesieniu do określonego w komentowanym przepisie układu procesowego odseparowanie czynności dowodowych dokonywanych na podstawie art. 378a KPK od rozprawy głównej, która podlega przerwaniu lub odroczeniu ze względu na usprawiedliwione niestawiennictwo oskarżonego lub obrońcy na tym forum. [...] zasadnicze wątpliwości nasuwa założenie wyizolowania (oddzielenia) czynności dowodowych dokonywanych na podstawie tego przepisu w wypadku usprawiedliwione- 
postępowania dowodowego na zasadach, o których mowa w art. 378a k.p.k., ma nastąpić w warunkach rozprawy głównej (również z uwagi na treść art. 410 k.p.k.), nie można odmówić racji założeniu, że ,rozprawę główną w tym terminie, w którym znalazłby zastosowanie przepis art. $378 \mathrm{a} \S 1$ k.p.k., wypełniałoby w całości przeprowadzenie czynności dowodowej, co do której zachodzi niebezpieczeństwo, że nie będzie jej można powtórzyć w toku dalszego postępowania sądowego"6.

Zwróćmy także uwagę, że ustawodawca nie ograniczył się w tym kontekście do żadnych konkretnych czynności dowodowych (wskazując ogólnie: „może przeprowadzić postępowanie dowodowe"), a jedynie wyłuszczył, że może być to również czynność przesłuchania świadków. W związku z tym może być to przeprowadzenie też takich czynności dowodowych, jak chociażby przesłuchanie biegłego czy konfrontacja biegłych, a więc takich czynności, w których percepcja, a więc odbiór wrażeń zmysłowych, jak również zrozumienie przekazywanych przez biegłego treści intelektualnych (teoretycznych i technicznych z zakresu określonej dyscypliny nauki) jest dla oskarżonego i jego obrońcy niezmiernie ważna. Skorzystanie przez sąd z uprawnienia, które daje mu art. 378a k.p.k., będzie więc pozbawiać oskarżonego lub jego obrońcę tych ważnych — z punktu widzenia prawa do obrony — przekazów informacji.

To jednak nie wszystko. Wcześniej wyrażony wniosek dotyczący sprzeczności wskazanych już przepisów prawnych (art. 378a k.p.k. i art. 386 § 2 k.p.k. w zw. z art. $16 \S 1$ k.p.k.) można by próbować odeprzeć poprzez odwołanie do przytoczonego już art. $353 \S 4$ k.p.k., który przewiduje istniejący w chwili zawiadomienia o terminie rozprawy lub wezwania na rozprawę obowiązek pouczenia między innymi o treści art. 378a k.p.k. Innymi słowy można argumentować następująco: pouczenie oskarżonego w trybie art. $353 \S 4$ k.p.k. o możliwości przeprowadzenia postępowania dowodowego podczas jego nieobecności, nawet gdyby usprawiedliwił on swoje niestawiennictwo, przesuwa obowiązek pouczenia z art. $386 \S 2$ k.p.k. do momentu, kiedy oskarżony stawi się na terminie rozprawy. Słowem, można uznać, że pouczenie, o którym traktuje art. 353 § 4 k.p.k., o możliwości przeprowadzenia postępowania dowodowego pod nieobecność oskarżonego

go niestawiennictwa na rozprawie oskarżonego lub jego obrońcy z rozprawy głównej, podlegającej w takim wypadku przerwaniu lub odroczeniu. Założenie to nie tylko razi sztucznością, ale przede wszystkim rodzi szereg istotnych pytań, m.in. dotyczących tego, jakie jest forum czynności dowodowych, zwłaszcza przesłuchania świadków, w razie zastosowania art. 378a § $1 \mathrm{KPK}$, skoro nie jest nim rozprawa główna, kto może w nich uczestniczyć, czy odbywają się one w sposób jawny dla publiczności. [...] To, co wydaje się jednak najważniejsze w aspekcie oceny przedstawionego założenia, wiąże się ze spostrzeżeniem, że jego przyjęcie, oznaczające w istocie, że określone czynności dowodowe w sprawie, która trafiła do rozpoznania na rozprawie głównej, są przeprowadzane poza tym forum, wyklucza w gruncie rzeczy możliwość bezpośredniego oparcia na uzyskanych w ich wyniku dowodach ustaleń faktycznych stanowiących podstawę wyroku. Przesądza o tym treść art. 410 KPK, zgodnie z którym podstawę taką mogą stanowić wyłącznie okoliczności ujawnione na rozprawie głównej” - J. Zagrodnik, [w:] Art. 378 a k.p.k., red. J. Skorupka, Warszawa 2020, Legalis.

6 Ibidem. 
stanowi pełne i przekonujące uzasadnienie wprowadzenia do kodeksu postępowania karnego art. 378a k.p.k. w obowiązującym kształcie. Tak jednak nie jest, biorąc pod uwagę treść art. 6 k.p.k. Wprowadzenie przez ustawodawcę pouczenia o możliwości prowadzenia postępowania dowodowego pod nieobecność (zwłaszcza usprawiedliwioną) oskarżonego stoi bowiem w sprzeczności z jego prawem do obrony, które wyraża się między innymi w prawie do zadawania pytań osobom przesłuchiwanym oraz $\mathrm{w}$ prawie do wypowiedzenia się na temat każdego dowodu. Nie można także uznać, że prawo do obrony oskarżonego ulega wyłączeniu w sytuacji, gdy oskarżony nie jest obecny podczas przeprowadzania czynności dowodowej. Zwróćmy zatem uwagę, w jaki sposób ustawodawca podjął próbę ochrony prawa do obrony oskarżonego, który nie uczestniczył w przeprowadzaniu czynności dowodowej z powodu obiektywnych przeszkód do stawiennictwa.

\section{WNIOSEK O UZUPEŁNIAJĄCE PRZEPROWADZENIE DOWODU}

\section{Zgodnie z $§ 3$ art. 378a k.p.k.:}

Jeżeli sąd przeprowadził postępowanie dowodowe podczas nieobecności oskarżonego lub obrońcy w wypadku, o którym mowa w $§ 1$, oskarżony lub obrońca może najpóźniej na kolejnym terminie rozprawy, o którym był należycie zawiadomiony przy jednoczesnym braku procesowych przeszkód do jego stawiennictwa, złożyć wniosek o uzupełniające przeprowadzenie dowodu przeprowadzonego podczas jego nieobecności. Prawo do złożenia wniosku nie przysługuje, jeżeli okaże się, że nieobecność oskarżonego lub obrońcy na terminie rozprawy, na którym przeprowadzono postępowanie dowodowe na podstawie $\S 1$, była nieusprawiedliwiona.

Stawiennictwo oskarżonego lub obrońcy na termin rozprawy implikuje obowiązek przewodniczącego pouczenia go o możliwości złożenia wniosku o uzupełniające przeprowadzenie dowodu przeprowadzonego podczas jego nieobecności, a także umożliwia mu wypowiedzenie się co do tej kwestii (§ 7 art. 378a k.p.k.). Słowem, możliwość złożenia wniosku o uzupełniające przeprowadzenie dowodu przeprowadzonego podczas jego nieobecności przysługuje wyłącznie oskarżonemu lub jego obrońcy, który należycie usprawiedliwił swoje niestawiennictwo. Oskarżony (lub obrońca), który nie stawił się na terminie rozprawy, na którym został przeprowadzony dowód, a który to nie usprawiedliwił swojego niestawiennictwa, nie ma zatem uprawnienia do złożenia wniosku o uzupełniające przeprowadzenie dowodu przeprowadzonego podczas jego nieobecności. W razie złożenia takiego wniosku powinno nastąpić pozostawienie go bez rozpoznania ${ }^{7}$. Wniosek o uzupełniające przeprowadzenie dowodu jest specyficznym wnioskiem dowodowym oraz winien spełniać dwa kryteria: kryterium czasu i kryterium treści.

\footnotetext{
7 Ibidem.
} 


\subsection{KRYTERIUM CZASU}

Pierwsze z nich dotyczy tego, do kiedy ów wniosek dowodowy może zostać złożony, a jest nim najpóźniej kolejny termin rozprawy, o którym oskarżony i jego obrońca byli należycie zawiadomieni, przy jednoczesnym braku procesowych przeszkód do stawiennictwa (art. 378a § 3 k.p.k.). Choć nie wynika to jednoznacznie z wykładni językowej, to jednak wykładnia funkcjonalna nakazuje przyjąć, że czynność dowodowa przeprowadzona pod nieobecność oskarżonego lub jego obrońcy nie może być czynnością dokonaną na ostatnim terminie rozprawy, ponieważ nie ma już kolejnego terminu rozprawy, na którym można byłoby złożyć wniosek o uzupełniające przeprowadzenie dowodu ${ }^{8}$. Co prawda wskazany przepis prawny stanowi o tym, że przedmiotowy wniosek może zostać złożony „najpóźniej na kolejnym terminie rozprawy", to jednak w układzie procesowym, w którym na kolejnym terminie rozprawy miałoby — zgodnie z założeniem sądu — nastąpić zamknięcie przewodu sądowego i przejście do udzielania głosów końcowych, to złożenie wniosku o uzupełniające przeprowadzenie dowodu powinno nastąpić do momentu zamknięcia przewodu sądowego. Taki wynik wykładni potwierdza treść art. $405 \S 1$ k.p.k., zgodnie z którym „Po przeprowadzeniu dowodów dopuszczonych w sprawie przewodniczący zapytuje strony, czy wnoszą o uzupełnienie postępowania dowodowego, i w razie odpowiedzi przeczącej — zamyka przewód sądowy"9.

Niedotrzymanie terminu, jakim jest najpóźniej kolejny termin rozprawy, sprawia, że prawo do złożenia takiego wniosku wygasa i w dalszym postępowaniu nie jest dopuszczalne podnoszenie zarzutu naruszenia gwarancji procesowych, w szczególności prawa do obrony (§ 4 art. 378a k.p.k.). Tym samym ustawodawca wprowadził prekluzję dowodową, co może implikować założenie o zmianie paradygmatu myślenia nad postępowaniem dowodowym. Choć w zamyśle projektodawcy „Brak takiego terminu prowadziłby zaś do dezorganizacji postępowania"10, to jednak można ogólnie uznać, że wprowadzenie prekluzji dowodowej może prowadzić do niebezpieczeństwa związanego z potencjalnym utrudnieniem w dotarciu do prawdy materialnej (art. $2 \S 2$ k.p.k.). Zawsze także rodzi pytanie

8 W sporządzonym na etapie projektowania ustawy piśmie Rzecznika Praw Obywatelskich odczytujemy: „Projektowana możliwość »uzupełniającego« przeprowadzenia dowodu na wniosek oskarżonego lub obrońcy nie daje gwarancji unicestwienia ewentualnych negatywnych skutków procesowych, wynikających z przeprowadzenia dowodu podczas nieobecności ww. uczestników postępowania. Ponadto powstaje pytanie, jak się ma powyższa regulacja do spraw, w których termin rozprawy, na której dowód został przeprowadzony mimo nieobecności oskarżonego i obrońcy, jest ostatnim terminem w sprawie. Z literalnego brzmienia projektowanego przepisu wynika, że z uprawnienia do złożenia wniosku można skorzystać wyłącznie na najbliższym terminie, zatem nie będzie można skorzystać z niego, jeśli nie będzie kolejnego terminu w sprawie. Taka konstrukcja jednoznacznie pozostaje w sprzeczności ze standardem wynikającym z art. 42 Konstytucji RP oraz art. 6 § 3 EKPCz" — pismo RPO, II.510.1319.2018.

9 Odmiennie J. Zagrodnik, który wskazał, że wniosek o uzupełniające przeprowadzenie dowodu można zgłosić również w ramach przemówień końcowych; zob. J. Zagrodnik, op. cit.

$10 \mathrm{Z}$ uzasadnienia projektu ustawy nowelizacyjnej, s. 44. 
o pogodzenie prekluzji dowodowej z prawem do obrony. Zwróćmy bowiem uwagę, że spóźniony wniosek dowodowy nie jest tożsamy z niezasadnym wnioskiem dowodowym. Zatem spóźniony, albowiem złożony już po kolejnym terminie rozprawy wniosek dowodowy dotyczący tego dowodu, który na rozprawie został już przeprowadzony, będący wnioskiem w pełni zasadnym oraz istotnym z punktu widzenia tego, czy został popełniony czyn zabroniony (na przykład w sytuacji, w której nastąpiło już przesłuchanie świadka podczas nieobecności oskarżonego lub jego obrońcy, któremu nie zadano pytań na takie okoliczności, na jakie wskazał obrońca w spóźnionym wniosku dowodowym, a które to okoliczności mogłyby mieć istotne znaczenie z punktu widzenia ustalenia popełnienia czynu zabronionego), nie może zostać uwzględniony, gdyż prawo do złożenia takiego wniosku bezwzględnie wygasa (nie znajdzie tutaj zastosowania art. $170 \S 4$ k.p.k. $\mathrm{z}$ uwagi na to, że nie wydaje się w takim wypadku postanowienia o oddaleniu wniosku dowodowego, o czym będzie mowa dalej).

Ogólnie ujmując, wygaśnięcie prawa oznacza, że po zakreślonym przez ustawodawcę terminie takie prawo już nie istnieje. Brak uprawnienia do dokonania określonej czynności karnoprocesowej (w tym wypadku złożenia wniosku o uzupełniające przeprowadzenie dowodu) oznacza, że czynność dokonana po upływie zakreślonego terminu nie może być rozpoznana jako czynność karnoprocesowa danego typu. Skoro nie może być ona rozpoznana jako czynność karnoprocesowa określonego typu, to albo nie jest wymagane wydanie żadnej decyzji procesowej wyrażającej fakt upływu określonego terminu na dokonanie określonej czynności karnoprocesowej, a wówczas taki wniosek pozostawia się bez rozpoznania (podobnie w sytuacji złożenia wniosku przez osobę nieuprawnioną albo gdy nie istnieją przesłanki do jego złożenia, na przykład jak w opisanej wcześniej sytuacji związanej ze złożeniem wniosku o uzupełniające przeprowadzenie dowodu przez oskarżonego lub jego obrońcę, który należycie nie usprawiedliwił swojego niestawiennictwa na terminie rozprawy, na którym przeprowadzono dowód), albo taka konieczność istnieje, gdy ustawodawca przewidział to expressis verbis.

Choć mowa w tym wypadku o wniosku dowodowym (specyficznym, jako że jest to wniosek o uzupełniające przeprowadzenie dowodu), to należałoby rozważyć, czy — już po złożeniu takiego wniosku — istnieje konieczność wydania decyzji procesowej stwierdzającej fakt wygaśnięcia prawa do złożenia takiego wniosku z uwagi na upływ terminu do jego złożenia. Artykuł 378a k.p.k. expressis verbis nie stanowi o wydaniu w tym przedmiocie żadnej decyzji procesowej, traktuje jedynie o wygaśnięciu prawa do złożenia takiego wniosku. Natomiast zgodnie z art. 368 § 1 k.p.k. „O przychylnym załatwieniu wniosku dowodowego strony, któremu inna strona nie sprzeciwiła się, rozstrzyga ostatecznie przewodniczący; w innych wypadkach sąd wydaje postanowienie". Jednakże przesłanki oddalenia wniosku dowodowego uregulowane są expressis verbis $\mathrm{w}$ art. 170 $\S 1$ k.p.k. i tworzą one katalog zamknięty (katalog przesłanek, których nie można interpretować rozszerzająco). We wskazanym wcześniej kontekście związanym 
z upływem terminu na złożenie wniosku dowodowego nie posłuży nam jednak treść art. 170 k.p.k., który stanowi o przesłankach oddalenia wniosku dowodowego (art. $170 \S 1$ k.p.k.) oraz konieczności wydania postanowienia o oddaleniu wniosku dowodowego (art. $170 \S 3$ k.p.k.). Wśród przesłanek do oddalenia wniosku dowodowego nie odnajdujemy bowiem takiej, która traktowałaby o przekroczeniu ustawowo zakreślonego terminu do złożenia takiego wniosku. Artykuł 170 $\S 1$ pkt 6 k.p.k. wskazuje co prawda, że wniosek dowodowy oddala się, jeżeli został on złożony po zakreślonym przez organ procesowy terminie, o którym strona składająca wniosek została zawiadomiona, jednak — jak się wydaje — sytuacja opisana w treści art. 378a $\S 3$ k.p.k. ma inny charakter. Termin na złożenie wniosku o uzupełniające przeprowadzenie dowodu przeprowadzonego pod nieobecność oskarżonego nie jest bowiem terminem zakreślanym przez organ procesowy, ale terminem zakreślonym przez ustawodawcę. Organ procesowy nie jest uprawniony ani do skrócenia, ani do wydłużenia tego terminu. Nie znajdzie tutaj zastosowania również art. $170 \S 1$ pkt 1 k.p.k., ponieważ niedopuszczalność przeprowadzenia dowodu wiązana jest najczęściej z zakazami dowodowymi albo brakiem uprawnienia do dokonania określonej czynności karnoprocesowej ${ }^{11}$. $Z$ tego względu w odniesieniu do spóźnionego wniosku o uzupełniające przeprowadzenie dowodu przeprowadzonego pod nieobecność oskarżonego nie stosuje się art. 170 k.p.k. stanowiącego o oddaleniu wniosku dowodowego. Wydaje się zatem, że nie jest wymagane wydanie postanowienia stwierdzającego fakt upływu terminu na złożenie wniosku o uzupełniające przeprowadzenie dowodu. W tym wypadku nie wydaje się bowiem postanowienia o oddaleniu wniosku dowodowego, lecz - w świetle wskazanych uwag — pozostawia się taki wniosek bez rozpoznania.

Nie oznacza to jednak, że nie można wyobrazić sobie takich konfiguracji procesowych, w których sąd wyda postanowienie o oddaleniu wniosku dowodowego (wniosku o uzupełniające przeprowadzenie dowodu), na przykład opierając się na przesłance $\mathrm{z}$ art. $170 \S 1 \mathrm{pkt} 4$ k.p.k., chociażby gdy ponowne przesłuchanie świadka nie będzie możliwe $\mathrm{z}$ uwagi na jego wyjazd poza granice kraju ${ }^{12}$. Niemniej — jak już wskazano — okoliczności wyszczególnione w przepisie art. 170 $\S 1$ k.p.k. nie dotyczą sytuacji, w której doszło do przekroczenia terminu na złożenie wniosku dowodowego, który to termin został ustawowo zakreślony przez usta-

$11 \mathrm{Na}$ temat formuły niedopuszczalności czynności dowodowej wypowiadali się między innymi: R. Kmiecik, Konwalidacja i konwersja wadliwych dowodów, „Państwo i Prawo” 1989, nr 5, s. 91 n.; K. Woźniewski, Prawidłowość czynności procesowych w polskim procesie karnym, Gdańsk 2010, s. 170 n.; B. Janusz-Pohl, O konstrukcji niedopuszczalności czynności karnoprocesowej, „Ruch Prawniczy, Ekonomiczny i Socjologiczny” 2014, nr 4, s. 161 n.; eadem, Formalizacja $i$ konwencjonalizacja jako instrumenty analizy czynności karnoprocesowych w prawie polskim, Poznań 2017, s. 445 n.; S. Waltoś, Konwalidacja w procesie karnym, „Nowe Prawo” 1960, nr 4, s. 494; K. Marszał, Proces karny. Zagadnienia ogólne, Katowice 2008, s. 292; S. Śliwiński, Proces karny przed sądem powszechnym. Zasady ogólne, Warszawa 1948, s. 214 n.; M. Żbikowska, Ciężar dowodu w polskim procesie karnym, Warszawa 2019, s. $453 \mathrm{n}$.

12 J. Zagrodnik, op. cit. 
wodawcę. Przyjmując taką wykładnię, nie znajdzie w tym kontekście (zważmy - wyłącznie w odniesieniu do spóźnionego wniosku o uzupełniające przeprowadzenie dowodu) zastosowania również art. 170 § 4 k.p.k., zgodnie z którym oddalenie wniosku dowodowego nie stoi na przeszkodzie późniejszemu dopuszczeniu dowodu, chociażby nie ujawniły się nowe okoliczności. Należy jednak stanowczo uznać, że pozostawienie spóźnionego wniosku o uzupełniające przeprowadzenie dowodu bez rozpoznania nie stoi na przeszkodzie ponowieniu danej czynności dowodowej z inicjatywy sądu ${ }^{13}$.

\subsection{KRYTERIUM TREŚCI}

Kryterium treści wynika z art. 378a § 5 k.p.k. Zgodnie z tym przepisem: „We wniosku o uzupełniające przeprowadzenie dowodu oskarżony lub obrońca ma obowiązek wykazać, że sposób przeprowadzenia dowodu podczas jego nieobecności naruszał gwarancje procesowe, w szczególności prawo do obrony". Co za tym idzie - wskazany przepis prawny nie dotyczy treści przeprowadzonej czynności dowodowej (tak jak ma to miejsce na przykład w wypadku art. 170 § 1a k.p.k.), ale dotyczy sposobu przeprowadzenia dowodu. Oskarżony lub jego obrońca, składając wniosek o uzupełniające przeprowadzenie dowodu, ma obowiązek wykazać, że to sposób przeprowadzenia dowodu podczas jego nieobecności naruszał gwarancje procesowe, w szczególności prawo do obrony. W gruncie rzeczy ustawodawca wymaga, aby oskarżony lub jego obrońca rozpoznał na czas (najpóźniej do kolejnego terminu rozprawy), czy sposób przeprowadzenia dowodu był prawidłowy. W świetle wskazanego przepisu prawnego musi zatem istnieć korelacja między sposobem przeprowadzenia dowodu a naruszeniem gwarancji procesowych oskarżonego. Rozpoznanie przez oskarżonego lub jego obrońcę, że to sposób przeprowadzenia dowodu naruszał gwarancje procesowe, zwłaszcza prawo do obrony, jest zadaniem niezmiernie utrudnionym $\mathrm{z}$ uwagi na to, że oskarżony (lub jego obrońca) nie był przecież obecny podczas czynności przeprowadzenia dowodu, co rodzi pytanie, w jaki sposób ma on ustalić, że sposób przeprowadzenia takiej czynności naruszał jego gwarancje procesowe. Jedynym źródłem dla oskarżonego i jego obrońcy jest protokół z przeprowadzenia takiej czynności dowodowej.

Zastanówmy się teraz, co oznacza ten dość enigmatyczny fragment dyspozycji art. 378a $§ 5$ k.p.k., który stanowi, że ,sposób przeprowadzenia dowodu podczas jego nieobecności naruszał gwarancje procesowe, w szczególności prawo do obrony”. Mianowicie — ogólnie rzecz ujmując — zwrot „naruszał gwarancje procesowe" jest określeniem bardzo szerokim, obejmującym spektrum możliwych do urzeczywistnienia sytuacji, w tym takich, które mogą skutkować wadliwością,

13 Biorąc pod uwagę ogólne zasady związane z ponownym przeprowadzeniem czynności dowodowych. Szerzej na ten temat pisał Ł. Cora, Ponowienie czynności dowodowej w polskim procesie karnym (aspekty teoretyczne i prakseologiczne), „Ruch Prawniczy, Ekonomiczny i Socjologiczny” 2018, nr 4, Legalis. 
a nawet nieważnością czynności dowodowej. Innymi słowy sposób przeprowadzenia czynności dowodowej może być prawidłowy, a wówczas czynność dowodowa jest ważna i skuteczna (ważny jest również wytwór takiej czynności), albo nieprawidłowy, a wówczas czynność dowodowa jest wadliwa lub nieważna. Przyjmuje się, że w zależności od stopnia wadliwości przeprowadzonej czynności karnoprocesowej (naruszenia reguł formalizacji dla danej czynności) może być to czynność wadliwa, lecz skuteczna, albo wadliwa i w konsekwencji bezskuteczna ${ }^{14}$. Natomiast czynność nieważna (a więc gdy doszło do naruszenia reguł konstytutywnych dla danej czynności) zawsze jest czynnością, która nie może zrodzić skutków prawnych.

Szerokie interpretowanie zwrotu ,sposób przeprowadzenia dowodu podczas jego nieobecności naruszał gwarancje procesowe, w szczególności prawo do obrony" może doprowadzić do absurdu, albowiem taki sposób przeprowadzenia czynności dowodowej, który narusza gwarancje procesowe, a przez to wiedzie do wadliwości danej czynności, skutkującej jej bezskutecznością lub nieważnością danej czynności, musi doprowadzić do dyskwalifikacji wytworu takiej czynności dowodowej i to obligatoryjnie (bez wniosku strony) oraz — jeśli taka możliwość istnieje - ponowienia czynności dowodowej danego typu (tak zwana konwalidacja). Co za tym idzie - wskazany zwrot nie może być interpretowany szeroko, a więc musi zostać ograniczony tylko do takiego sposobu przeprowadzenia dowodu, który naruszał gwarancje procesowe powodujące wadliwość czynności karnoprocesowej, która nie implikuje jej bezskuteczności (gdy mamy bowiem do czynienia z bezskutecznością albo nieważnością czynności, czynność dowodowa powinna być przeprowadzona raz jeszcze albo z urzędu, albo na wniosek strony — nie będzie to jednak wniosek o uzupełniające przeprowadzenie dowodu, lecz o ponowne pełne przeprowadzenie określonej czynności dowodowej).

Taką interpretację potwierdzają dwa argumenty. Pierwszy z nich odwołuje się do rygoru związanego z niezłożeniem wniosku o uzupełniające przeprowadzenie dowodu $\mathrm{w}$ terminie. Zgodnie z $\S 4$ art. 378a k.p.k. w razie niezłożenia wniosku w terminie prawo do jego złożenia wygasa i w dalszym postępowaniu nie jest dopuszczalne podnoszenie zarzutu naruszenia gwarancji procesowych, w szczególności prawa do obrony, wskutek przeprowadzenia tego dowodu pod nieobecność oskarżonego lub jego obrońcy. Nie trzeba przekonywać, że rygor w postaci niedopuszczalności podnoszenia zarzutu naruszenia gwarancji procesowej powodującej wadliwość tej czynności w stopniu uzasadniającym jej bezskuteczność lub nieważność takiej czynności nie może mieć miejsca. Wyłączenie takiej możliwości prowadziłoby do uznania, że przeprowadzenie czynności dowodowej z naruszeniem gwarancji procesowych oskarżonego na określo-

14 Więcej w tym przedmiocie zob. T Gizbert-Studnicki, O nieważnych czynnościach prawnych w świetle koncepcji czynności konwencjonalnych, „Państwo i Prawo” 1975, nr 4, s. 70-82; B. Janusz-Pohl, Formalizacja i konwencjonalizacja..., s. 408 n., 496 n. 
nych zasadach nie może zostać podniesione przez oskarżonego jeszcze w trakcie toczącego się postępowania, na przykład w celu zdyskwalifikowania wytworu określonej czynności dowodowej oraz ponowienia takiej czynności. Natomiast bezsporne powinno być twierdzenie, że sąd, wydając wyrok, nigdy nie powinien opierać swoich ustaleń na takich środkach dowodowych, które będąc wytworami czynności dowodowych wadliwych w wysokim stopniu lub nieważnych, są nieważne (na przykład nieważne będą takie zeznania świadka, które zostały odebrane w warunkach wyłączenia swobody wypowiedzi). Zważmy, że wniosek ten dotyczy wyłącznie sytuacji, w której doszło do naruszenia gwarancji procesowej wskutek przeprowadzenia czynności dowodowej podczas nieobecności oskarżonego, które to naruszenie skutkuje bezskutecznością lub nieważnością danej czynności. W takiej sytuacji istnieje konieczność ponowienia czynności dowodowej i to bez wniosku oskarżonego (co za tym idzie — tym bardziej, gdy taki wniosek został złożony).

Drugi argument odwołuje się do charakteru wniosku oskarżonego, a mianowicie jest to wniosek o ,uzupełniające przeprowadzenie dowodu”. Wniosek o uzupełniające przeprowadzenie dowodu nie jest tym samym co wniosek o pełne ponowne przeprowadzenie dowodu. Nie chodzi tu zatem na przykład o pełne ponowne przesłuchanie świadka, ale o jego „dosłuchanie” $w$ określonym jedynie zakresie. Zgodnie bowiem z $\S 6$ art. 378a k.p.k. „W razie uwzględnienia wniosku o uzupełniające przeprowadzenie dowodu sąd przeprowadza dowód uzupełniająco, jedynie w zakresie, w którym wykazano naruszenie gwarancji procesowych, w szczególności prawa do obrony". Skoro uzupełniające przeprowadzenie dowodu ma być pewnym naddatkiem w stosunku do uprzednio dokonanej czynności dowodowej, to owa uprzednio dokonana czynność dowodowa musi być ważna i skuteczna. Nie można bowiem uzupełnić czynności nieważnej lub bezskutecznej (taką czynność można wówczas tylko ponowić w pełnym zakresie).

Podsumowując ten fragment rozważań, należy uznać, że treść art. 378a § 4 k.p.k. zawiera ograniczenie czasowe na złożenie wniosku dowodowego tylko w odniesieniu do takiej konfiguracji procesowej, w której wskutek przeprowadzenia danego dowodu podczas nieobecności oskarżonego lub obrońcy doszło do naruszenia gwarancji procesowych, w szczególności prawa do obrony, które to naruszenie nie mogło spowodować bezskuteczności lub nieważności danej czynności.

Warto pokusić się jeszcze o pewną refleksję odnośnie do użytego w $\S 4$ i 5 określenia „w szczególności prawa do obrony”. Można ją sprowadzić do następującego pytania: jakie sytuacje związane z naruszeniem prawa do obrony podczas przeprowadzania czynności dowodowej nie będą powodowały bezskuteczności lub nieważności takiej czynności? Aby możliwe było urzeczywistnienie art. 378a k.p.k. przy przyjęciu założenia o wykluczeniu takich naruszeń powodujących bezskuteczność lub nieważność czynności dowodowej, musimy choćby hipotetycznie wskazać takie sytuacje, o których możemy z jednej strony powiedzieć, że naruszają prawo do obrony, a z drugiej — że owo naruszenie nie powoduje bez- 
skuteczności lub nieważności czynności dowodowej15. Niestety projektodawca, proponując kształt wskazanej enigmatycznej przesłanki „,sposób przeprowadzenia dowodu naruszał gwarancje procesowe, w szczególności prawo do obrony", nie wskazał w uzasadnieniu projektu ustawy przykładów takich naruszeń, „zręcznie” uciekając od tego problemu.

Na koniec powróćmy jeszcze do dyspozycji $§ 1$ art. 378a k.p.k. Jak już wskazywano, sąd może przeprowadzić postępowanie dowodowe pod nieobecność (usprawiedliwioną) oskarżonego tylko w szczególnie uzasadnionych wypadkach. $\mathrm{Z}$ założenia zatem norma ta ma być stosowana wyjątkowo. Co za tym idzie - zasadą winno być jednak przeprowadzanie postępowania dowodowego przy obecności oskarżonego lub jego obrońcy, zwłaszcza gdy oskarżony lub jego obrońca chciał uczestniczyć w rozprawie, lecz z powodów obiektywnych uczestniczyć w niej nie mógł i należycie usprawiedliwił swoje niestawiennictwo. Określenie „W szczególnie uzasadnionych wypadkach” — jak się wydaje — dotyczy takich sytuacji, w których istnieje „zagrożenie dla dowodu”, przykładowo, gdy jest wysokie prawdopodobieństwo, że świadka nie będzie można w późniejszym terminie

15 Należy jeszcze odpowiedzieć na pytanie, jakie okoliczności może podawać oskarżony lub jego obrońca we wniosku o uzupełniające przeprowadzenie dowodu. Ustaliliśmy już, że muszą to być takie okoliczności, które nie są związane z bezskutecznością lub nieważnością danej czynności. Zwróćmy uwagę na propozycję zaprezentowaną przez J. Zagrodnika. Autor pisał: „wydaje się konieczne szersze ujęcie zakresu pojęciowego zwrotu »sposób przeprowadzenia dowodu« na gruncie komentowanego przepisu, uwzględniające - w przypadkach przeprowadzenia dowodu z zeznań świadka — pozbawienie oskarżonego lub obrońcy możliwości odebrania bezpośrednich wrażeń oraz poczynienia spostrzeżeń w związku z przesłuchaniem z racji dokonania tej czynności dowodowej podczas ich nieobecności, mimo że była ona usprawiedliwiona. Przy takim podejściu interpretacyjnym realne staje się spełnienie analizowanego wymagania formalnego wniosku o uzupełniające przeprowadzenie dowodu, które mogłoby polegać np. na wskazaniu przez wnioskodawcę, że poprzez przeprowadzenie czynności dowodowej podczas jego usprawiedliwionej nieobecności został pozbawiony możliwości zadania określonych pytań świadkowi, a okoliczności, których wyjaśnieniu miałyby służyć te pytania, mające istotne znaczenie dla rozstrzygnięcia sprawy, nie zostały dostatecznie wyjaśnione $\mathrm{w}$ drodze pytań postawionych przez stronę przeciwną lub z urzędu. $\mathrm{Na}$ kanwie powyższych uwag nie sposób jednocześnie uchylić się od konstatacji, że z punktu widzenia legislacyjnej precyzji, a przede wszystkim realnego i jednoznacznego zagwarantowania prawa do obrony w konsekwencji zastosowania art. 378a § 1 KPK, należy oczekiwać zmiany komentowanego przepisu w zakresie, w jakim przewiduje on związanie określonych wymagań lub skutków procesowych z naruszeniem gwarancji procesowych ze względu na sposób przeprowadzenia dowodu (art. 378a § 5 KPK, a także art. 378a § 4 in fine KPK). Nie wydaje się zbyteczne podkreślenie, że gdyby w praktyce wymiaru sprawiedliwości z uznaniem spotkała się zaproponowana prokonstytucyjna i prokonwencyjna wykładnia art. 378a § 1 KPK, zakładająca jego zastosowanie w sytuacjach, w których zachodzi niebezpieczeństwo, że przeprowadzenie dowodu w toku dalszego postępowania nie będzie możliwe, to w aspekcie uwzględnienia wniosku o uzupełniające przeprowadzenie dowodu istotne byłoby wykazanie przez oskarżonego lub obrońcę nadal istniejącej możliwości jego przeprowadzenia" - J. Zagrodnik, op. cit. Wskazane przez autora przykłady wymagają zaakceptowania z uwagi na konieczność zracjonalizowania przepisu art. 378a k.p.k., a także zapewnienia prawa do obrony oskarżonego. Obecny kształt przepisu art. 378a k.p.k. zmusza więc do dokonywania licznych zabiegów interpretacyjnych, które w optymalny sposób zwiększą prawo do obrony oskarżonego. 
przesłuchać (na przykład w uwagi na możliwość śmierci świadka ze względu na postępującą chorobę lub wyjazd świadka za granicę), albo z uwagi na inne, obiektywnie istniejące trudności dowodowe, w których czas ma olbrzymie znaczenie z punktu widzenia możliwości przeprowadzenia danego dowodu.

O ile niewątpliwie w niektórych wypadkach istnieje ścisły związek między czasem a możliwością przeprowadzenia dowodu (związek odwrotnie proporcjonalny: im dłuższy czas, tym mniejsze prawdopodobieństwo przeprowadzenia dowodu), o tyle jednak nawet $\mathrm{w}$ takiej perspektywie nie można tracić $\mathrm{z}$ pola widzenia gwarancji procesowych oskarżonego. Jak bowiem w perspektywie gwarancji procesowych oskarżonego należałoby rozpoznać sytuację, gdy przeprowadzony pod nieobecność oskarżonego dowód, którego nie można ponownie przeprowadzić, byłby dowodem obciążającym i jednocześnie kluczowym do skazania oskarżonego? ${ }^{16} \mathrm{~W}$ gruncie rzeczy wskazany problem wprost wiąże się z pytaniem: czy we współczesnym prawie karnym procesowym wyżej ceni się szybkość postępowania i ewentualne możliwości dowodowe, czy gwarancje procesowe oskarżonego? Zwróćmy także uwagę, że istnieje możliwość wystąpienia takiej sytuacji, w której sposób przeprowadzenia czynności przesłuchania świadka podczas usprawiedliwionej nieobecności oskarżonego na rozprawie doprowadził do naruszenia gwarancji procesowych oskarżonego (takiego naruszenia, które nie powodowało bezskuteczności lub nieważności czynności dowodowej), oskarżony w związku z tym złożył w terminie wniosek o uzupełniające przeprowadzenie dowodu, którego nie można jednak przeprowadzić z uwagi na śmierć świadka lub jego wyjazd poza granice kraju. Dlaczego oskarżony ma ponosić negatywne konsekwencje takiego stanu rzeczy? Czy nie stoi temu na przeszkodzie jego prawo do obrony?

Językowa wykładnia art. 378a k.p.k. może prowadzić do jeszcze innego zagrożenia. Mianowicie w myśl $§ 1$ tego przepisu, jeżeli oskarżony lub jego obrońca nie stawił się na rozprawie, będąc zawiadomiony o jej terminie, sąd może przeprowadzić postępowanie dowodowe pod jego nieobecność. Czy zawiadomienie, o którym mowa $\mathrm{w}$ treści tego przepisu, musi być zawiadomieniem skutecznym? Słowem, czy musi być to należyte zawiadomienie, a zatem takie, które zostało skutecznie doręczone do adresata (biorąc pod uwagę zapisy dotyczące sposobów doręczania przesyłek sądowych)? Słowem, czy jedynie konieczność posiadania w aktach sprawy dowodu doręczenia zawiadomienia daje możliwość przeprowadzenia czynności dowodowej pod nieobecność oskarżonego lub jego obrońcy? Wydaje się, że taką interpretację należałoby przyjąć, jeżeli bowiem nie ma w aktach sprawy informacji o doręczeniu zawiadomienia o terminie rozprawy, to w jaki sposób zapewnić gwarancje procesowe oskarżonemu? Brak informacji o doręczeniu zawiadomienia o terminie rozprawy jest przejawem także braku informacji o tym, czy oskarżony został poinformowany o możliwości prowadzenia postępowania dowodowego podczas jego nieobecności (odwołanie do art. 353 § 4 k.p.k.). Choć istnieje założenie

16 Podkreślał to RPO w piśmie II.510.1319.2018. 
o tym, że de lege lata przeprowadzenie postępowania dowodowego pod nieobecność oskarżonego jest możliwe wyłącznie wówczas, gdy oskarżony został należycie zawiadomiony o terminie rozprawy, to jednak ustawodawca mógł mieć inny zamysł. W pierwszej kolejności zwróćmy uwagę na treść projektowanego art. 378a $\S 1$ k.p.k., który w pierwotnym kształcie brzmiał:

Jeżeli oskarżony lub obrońca nie stawił się na rozprawę i w aktach sprawy brak jest dowodu doręczenia mu zawiadomienia lub wezwania lub jeżeli zachodzi uzasadnione przypuszczenie, że niestawiennictwo wynikło z powodu przeszkód żywiołowych lub innych wyjątkowych przyczyn lub wtedy, gdy usprawiedliwił należycie niestawiennictwo, sąd może przeprowadzić postępowanie dowodowe w jego nieobecności, a w szczególności przesłuchać świadków, którzy stawili się na rozprawę, nawet jeżeli oskarżony nie złożył jeszcze wyjaśnień.

Projektodawca expressis verbis wskazywał zatem, że można prowadzić postępowanie dowodowe pod nieobecność oskarżonego, nawet gdy w aktach sprawy brakuje dowodu doręczenia mu zawiadomienia lub wezwania. Choć ostatecznie taki kształt przepisu art. 378a § 1 k.p.k. nie wszedł w życie, to jednak językowa wykładnia wszystkich jednostek redakcyjnych obowiązującego art. 378a k.p.k. może prowadzić do założenia, w świetle którego przyjmiemy, że dopuszczalne jest przeprowadzenie postępowania dowodowego podczas nieobecności oskarżonego, gdy co prawda został on zawiadomiony o terminie rozprawy, ale w aktach sprawy nie ma dowodu doręczenia mu tego zawiadomienia. Wniosek ten potwierdza treść $\S 3$ art. 378a k.p.k., który stanowi wprost nie tyle o zawiadomieniu, ile o „należytym" zawiadomieniu (wprost o należytym zawiadomieniu mowa także na przykład w art. 117 § 1 i $\S 3 a$ k.p.k. ${ }^{17}$ ). Co za tym idzie — w sytuacji dotyczącej tego terminu rozprawy, na którym przeprowadzono dowód podczas usprawiedliwionej nieobecności oskarżonego lub jego obrońcy, mowa o „zawiadomieniu” o terminie rozprawy, podczas gdy tam, gdzie chodzi o kolejny termin rozprawy, na którym należy przeprowadzić dowód uzupełniająco, mowa już o „należytym zawiadomieniu”. Przyjęcie takiej interpretacji, wprost odwołującej się do wykładni językowej, może prowadzić do niebezpieczeństwa w postaci naruszenia prawa do obrony oskarżonego, a ponadto stałoby w sprzeczności z treścią art. 117 § 2 k.p.k., zgodnie z którym „Czynności nie przeprowadza się, jeżeli osoba uprawniona nie stawiła się, a brak dowodu, że została o niej powiadomiona". W związku z tym wykładnia systemowa oraz funkcjonalna, a także zasada lojalności procesowej wobec oskarżonego nakazuje przyjąć, że aktualizacja okoliczności, o których mowa w treści art. 378a $\S 1$ k.p.k. (a więc możliwość przeprowadzenia postępowania dowodowego podczas należycie usprawiedliwionej nieobecności oskarżonego lub jego obrońcy), może na-

17 Choć uczciwie należy wskazać, że kodeks postępowania karnego niejednokrotnie w odniesieniu do pewnych przepisów posługuje się zwrotem „należycie zawiadomiony” (tak na przykład w art. $343 \S 2$ k.p.k., art. 387 § 2 k.p.k., art. 450 § 3 k.p.k.), w odniesieniu zaś do innych traktując jedynie o „zawiadomieniu” (tak na przykład w art. 376 § 2 k.p.k., art. 377 § 3 k.p.k.). 
stąpić wyłącznie wówczas, gdy doszło do należytego zawiadomienia o terminie rozprawy, a w aktach sprawy znajduje się potwierdzenie doręczenia przesyłki sądowej.

\section{PODSUMOWANIE}

Należy przyznać, że treść przepisu art. 378a k.p.k. w obowiązującym kształcie wydaje się stać w sprzeczności z niektórymi przepisami ustawy (art. $386 \S 2$ k.p.k. i art. $16 \S 1$ k.p.k.). Obowiązek informacyjny, o którym mowa w art. 353 $\S 4$ k.p.k., dotyczący między innymi konieczności poinformowania oskarżonego o możliwości prowadzenia postępowania dowodowego pod jego nieobecność, nie likwiduje problemów, które pojawiają się w związku z interpretacją art. 378a k.p.k. Obowiązujący kształt tego przepisu prawnego stanowi poważne ograniczenie prawa do obrony oskarżonego. Założenia tego nie zmienia fakt wprowadzenia przez ustawodawcę możliwości złożenia przez oskarżonego lub jego obrońcę wniosku o uzupełniające przeprowadzenie postępowania dowodowego. Stwierdzenie, że dopuszczalne jest złożenie takiego wniosku tylko wówczas, gdy sposób przeprowadzenia dowodu naruszał gwarancje procesowe oskarżonego, a w szczególności jego prawo do obrony, jest wysoce problematyczne. Wniosek ten nie może dotyczyć wszystkich naruszeń, a konkretnie takich, które spowodowały bezskuteczność lub nieważność czynności dowodowej. Ustalenie, jakie zatem okoliczności mogą być podstawą złożenia wniosku o uzupełniające przeprowadzenie dowodu, wymaga dokonywania takich zabiegów interpretacyjnych, które ostatecznie będą prowadzić do zapewnienia prawa do obrony oskarżonemu. Wątpliwości budzi także charakter terminu na złożenie rzeczonego wniosku o uzupełniające przeprowadzenie postępowania dowodowego. Biorąc pod uwagę wszystkie wyrażone w niniejszym artykule wątpliwości, należy wyrazić postulat gruntownego zmodyfikowania treści przepisu art. 378a k.p.k., o ile nie jego usunięcia z ustawy karnoprocesowej.

\section{EVIDENCE PROCEEDINGS DURING THE JUSTIFIED ABSENCE OF THE ACCUSED OR HIS DEFENSE COUNSEL}

Summary

The subject of study is an analysis of the content of art. 378a of the Code of Criminal Procedure, added to the Code of Criminal Procedure on October 5, 2019. The legal provision under examination allows evidence to be taken in the absence of the accused or his defense counsel, even if it is justified by the absence. The author considers the legitimacy of introducing art. 378a of the Code of Criminal Procedure, and also takes into account the correctness of its construction. As a result of these considerations, he finds many flaws in the applicable legal regulations and tries to mitigate the 
negative effects of the introduction to the Polish legal system of the possibility of taking evidence during a duly substantiated absence of the accused or his defender at the trial.

Keywords: absence of the accused at the trial, evidence proceedings in the absence of the accused, evidence proceedings, right of defense, the accused

\section{BIBLIOGRAFIA}

Cora Ł., Ponowienie czynności dowodowej w polskim procesie karnym (aspekty teoretyczne i prakseologiczne), „Ruch Prawniczy, Ekonomiczny i Socjologiczny” 2018, nr 4.

Drajewicz D., Nieobecność oskarżonego na rozprawie głównej (art. 376 k.p.k.), „Prokuratura i Prawo" 2014, nr 5.

Drajewicz D., Nieobecność oskarżonego na rozprawie głównej (art. 377 k.p.k.), „Prokuratura i Prawo" 2014, nr 7-8.

Drajewicz D., Nieobecność oskarżonego na rozprawie w znowelizowanym Kodeksie postępowania karnego, „Monitor Prawniczy” 2015, nr 11.

Gizbert-Studnicki T., O nieważnych czynnościach prawnych w świetle koncepcji czynności konwencjonalnych, „Państwo i Prawo” 1975, nr 4.

Janusz-Pohl B., Formalizacja i konwencjonalizacja jako instrumenty analizy czynności karnoprocesowych w prawie polskim, Poznań 2017.

Janusz-Pohl B., O konstrukcji niedopuszczalności czynności karnoprocesowej, „Ruch Prawniczy, Ekonomiczny i Socjologiczny" 2014, nr 4.

Kmiecik R., Konwalidacja i konwersja wadliwych dowodów, „Państwo i Prawo” 1989, nr 5.

Marszał K., Proces karny. Zagadnienia ogólne, Katowice 2008.

Śliwiński S., Proces karny przed sąem powszechnym. Zasady ogólne, Warszawa 1948.

Waltoś S., Konwalidacja w procesie karnym, „Nowe Prawo” 1960, nr 4.

Woźniewski K., Prawidłowość czynności procesowych w polskim procesie karnym, Gdańsk 2010. Zagrodnik J., [w:] Art. 378 a k.p.k., red. J. Skorupka, wyd. 4, Warszawa 2020, Legalis.

Żbikowska M., Ciężar dowodu w polskim procesie karnym, Warszawa 2019. 